\title{
Sensitivity Analysis in Research of Construction of Agricultural Buildings Focused on Poultry Farming
}

\author{
Vít Malinovský
}

Department of System Engineering, Faculty of Economics and Management, Czech University of Life Sciences Prague, Czech Republic

\begin{abstract}
Both heat comfort and energy saving represent important parameters of agriculture buildings environment. Selecting material composition for perimeter walls (in course of both new building construction and reconstruction of existing ones) can aid to eliminate heat load of interior environment. Non-stationary processes taking place in building constructions in connection with building interaction with exterior environment and installed ventilating and heating systems are affected by a number of factors that can be well modelled by help of simulation methods and verified by experimental measuring. This work deals with analysing building construction from viewpoint of material used materials and changing their different physical parameters in order to achieve an optimal perimeter construction composition for agriculture building with regard to poultry farms.
\end{abstract}

\section{Keywords}

Economical operation, sensitivity analysis, system analysis, system model, poultry farming, economy of agricultural engineering, heating energy economy, temperature time characteristics, building temperature interaction.

Malinovský, V. (2019) "Sensitivity Analysis in Research of Construction of Agricultural Buildings Focused on Poultry Farming", AGRIS on-line Papers in Economics and Informatics, Vol. XI, No. 1, pp. 65-73. ISSN 1804-1930. DOI 10.7160/aol.2019.110107.

\section{Introduction}

The primary aim of the work is economical optimization employed during a project phase of poultry house construction designing and, at the same time, creating a designer's support tool for decision making concerning selection of proper building materials (and construction configuration) focused on future costs associated with heating and, thus, with costs spent to heating energy. In fact, an unsuitable construction design may cause completely wasteful operation related to excess costs and depreciation of business plans. The following method provides designers with ability to select both material optimum types and sizes ensuring future economical operation of the realized poultry house.

In association with development of animal farming, importance of heating energy economy and, concurrently, ambient temperature well-being constantly increases. For that reason, constructors should place appropriate emphasis on non-stationary processes in the area of building temperature interaction with outer environment as well as with installed heating and ventilation systems (Veverka et al., 1992). Building objects of poultry farms have to provide protection against excessive heat losses in cold macroclimatic conditions and, concurrently, to avoid excessive heat penetrating during hot time periods (Chloupek, 2012). Often unresolved aspects of thermal and insulating properties of perimeter constructions of poultry barn envelope or inappropriately designed or improperly used ventilation systems causing heat losses represent a part of the lacks of existing poultry farm buildings. Heat losses caused by penetrating through building construction are wholly useless and should be as more as possibly eliminated. Under optimum conditions, computation macro- and microclimatic values for thermal and insulating properties of walls and ceilings of poultry barns should eliminate water condensation on inner surface of the constructions. Especially during cold timer periods, negative heat balance of poultry barn spaces intended for breeding of young birds not having fully developed thermoregulation must be compensated by additional heating (Výmola et al., 1995). 
By help of a mathematic model of a poultry farm building construction, it is possible to simulate and study heat behaviour of each structural element in response to time changes caused by both outdoor temperature and indoor heating system. This method is applicable for indoor non-stationary heat processes analysis as well as for computer-controlled heating optimization (Cooke and DeBaerdemaeker, 1975).

This method was first time introduced by Professor Jiří Pánek, the former dean of the Faculty of Civil Engineering at CTU in Prague and, afterwards, it was enhanced by Professor Petr Moos and Associate professor Dalibor Vytlačil, both of them of the same institute. Later, senior lecturer Vít Malinovský (1993) worked up a method and carried out its application on particular building constructions together with a comparative analysis of the obtained results. At the Department of Building Equipment at CTU, the team led by Professor Miroslav Jokl developed the special application ANATH for analysis and synthesis intended for calculating heat responses at different building structural configurations.

\section{Materials and Methods}

Climate inside a poultry house comprises a set of environmental factors influencing wellbeing and health of a poultry flock. Particularly younger birds are sensitive to the inner climate consisting of five main factors reliant to building construction aspects: temperature, relative humidity, air composition, air speed and movement, and light. The first four of them are directly related to the interior temperature conditions. That is why, designers have to pay strong attention to a constructional side of planned objects of poultry houses - well done project radically affect success rate of future poultry breeding.

The most important factor for breeding birds is so called micro-climate i.e. the temperature closely encircling animals. Since interior temperature (without considering air circulation) can be characterized as a function of inner height - when the lowest values occur at a floor level and the highest at a ceiling - location of animals plays an significant part in creating environmental comfort. Taking this fact into consideration, satisfactory heat \& costs saving can be achieved. Use of breeding rings may be given as an example. Layers keep their body temperature approximately constant within the range of $41{ }^{\circ} \mathrm{C}$ and $42.3{ }^{\circ} \mathrm{C}$. Ideal ambient temperature for both layers (and broilers) lies between $20{ }^{\circ} \mathrm{C}$ and $24{ }^{\circ} \mathrm{C}$ and, with decreasing temperature, they require more feed to be able to maintain body temperature. Contrarily, higher temperatures cause worsening of egg weight as well as shell quality. A table of recommended temperatures for layers and broilers follow (Hulzebosch, 2005):

\begin{tabular}{|c|c|c|c|c|}
\hline \multirow{2}{*}{$1^{\text {st }}$ day } & $1^{\text {st }}$ & $2^{\text {nd }}$ & $3^{\text {rd }}$ & $4^{\text {th }}$ \\
\cline { 2 - 5 } & \multicolumn{4}{|c|}{ week of decrease } \\
\hline $32-34^{\circ} \mathrm{C}$ & $30^{\circ} \mathrm{C}$ & $26^{\circ} \mathrm{C}$ & $22^{\circ} \mathrm{C}$ & $20^{\circ} \mathrm{C}$ \\
\hline
\end{tabular}

Source: Hulzebosch, J. (2005)

Table1: Recommended temperatures for layers and broilers.

For the purpose of practical demonstration, a common and simple type of a poultry house object was selected. The paper comprises problems of the 3D model construction based on a real poultry house (on Figures $1 \mathrm{a}$ and $1 \mathrm{~b}$ ), mathematic theory of sensitivity analysis including calculation methods of temperature interior responses on exterior temperature values and, in the Results section, simulating of temperature courses for three different types of perimeter wall construction.

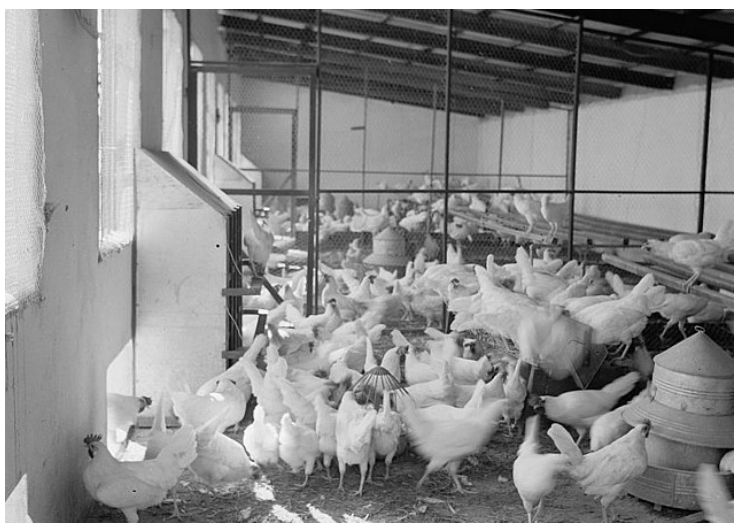

Source: free photo bank of WikiMedia

Figure 1a: Typical poultry house object used for mathematic model.

For describing problems of heat transfer sensitivity for parameters of building constructions, a simplified 3D-model of a poultry farm shown on Figures $1 \mathrm{a}$ and $1 \mathrm{~b}$ was considered. This poultry farm represents a single-space building object of single-layer perimeter wall very appropriate as an initial base for a particular system model scheme creation. Also a glass-walled part is taken into the consideration for temperature changes calculation (Moos, Vytlačil 1991).

This 3D-model is used for creating a particular scheme of a thermal circuit - handled as an electric circuit - representing a construction part of the poultry farm building object (Sonderegger, 1977). 


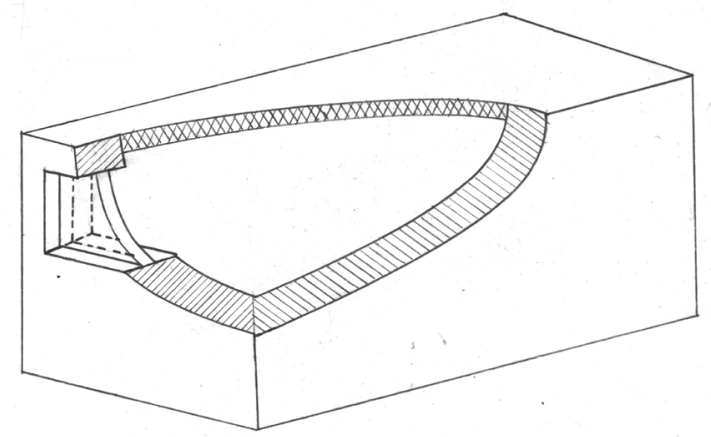

Source: Autor's own drawing

Figure 1b: Object scheme for system model creation.

Further, the thermal circuit considered as the building object system macromodel shown on Figure 2 based on the object scheme is used for entering input parameters for calculation carried on by ANATH application (Moos, Vytlačil 1991, Malinovský 1993). Numbers at the macromodel nods on Figure 2 represent selected temperature nods: $T_{o}=T_{1}$ on outer surface of perimeter wall, $T_{2}$ on inner surface of perimeter wall, $T_{3}=T_{i}$ in interior, and $T_{4}$ on heating body (Jokl, 1989).

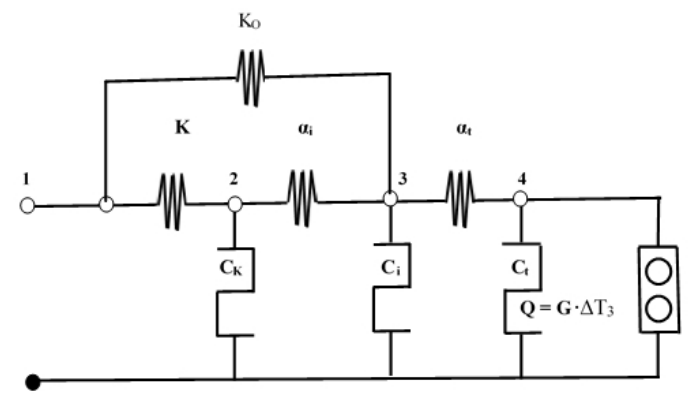

Source: Malinovský, V. (1989)

Figure 2: Particular scheme of examined system model.

1, 2, 3, 4 thermal circuit (system macromodel nods;

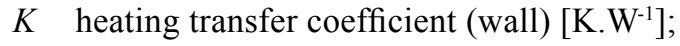

$K_{0}$ heating transfer coefficient (glass-walled part) $\left[\mathrm{K} . \mathrm{W}^{-1}\right]$;

$C_{K}$ heat capacity of perimeter wall [W.h.K ${ }^{-1}$;

$C_{i}$ heat capacity of interior [W.h.K ${ }^{-1}$;

$C_{t}$ heat capacity of heating system [W.h.K. ${ }^{-1}$;

$Q$ regulation factor $\left[\mathrm{W} \cdot \mathrm{K}^{-1}\right]$;

$\alpha_{i}$ heat transfer from perimeter wall to interior [K. W' ${ }^{-1}$;

$\alpha_{t}$ heat transfer from heating system to interior [K. $\left.\mathrm{W}^{-1}\right]$.

For simplicity, individual parameters are modelled by help of elements with concentrated parameters (Malinovský, 2018). Temperatures changes within the adjacent areas of stabilized state can be determined through a system of differential equations that could be - after Laplace transform - represented in matrix form:

$\left[\begin{array}{l}Q_{1} \\ Q_{2} \\ Q_{3} \\ Q_{4}\end{array}\right]=\left[\begin{array}{cccc}K+K_{0} & -K & \alpha_{i} & 0 \\ -K & K+\alpha_{i}+p \cdot C_{K} & -\propto_{i} & 0 \\ -K_{0} & -\alpha_{i} & \alpha_{i}+K_{0}+\alpha_{i}+p \cdot C_{i} & -\alpha_{i}\end{array}\right] \cdot\left[\begin{array}{c}T_{1} \\ T_{2} \\ T_{3} \\ T_{4}\end{array}\right]$

An image of Laplace transform of temperature change within the interior $\left(T_{i}\right)$ initiated by change of outer temperature $\left(T_{o}\right)$ can be determined in the following form:

$T_{3}=\frac{\Delta_{13}}{\Delta_{11}} \cdot T_{1}=F\left(p, x_{1}, x_{2} \ldots x_{n}\right) \cdot T_{1}$

$p$ Laplace operator

$x_{i}$ heat properties of construction and heating $\operatorname{system}\left(K_{(x)}, C_{(x)}, Q \ldots\right)$

Natural heat transfer is a typical process continuously changing in time. During the process, also transfer parameters show changes and some interesting relations among their values occur (Wachowicz, 2016). Amount by which the heat transfer is sensitive for changing individual partial parameters is very worth of detail research (Pöttgen et al., 2016). Therefore, a definition of heat transfer sensitivity was introduced. If linear approximation in the area of parameter $\mathrm{x}$ nominal value is carried out - as shown on Figure 3 - sensitivity of function $F(p, x)$ to parameter $x$ can be determined as derivation (2).

$S_{x}^{F}(p, x)=\left.\frac{d F(p, x)}{d x}\right|_{x=x_{q}}$

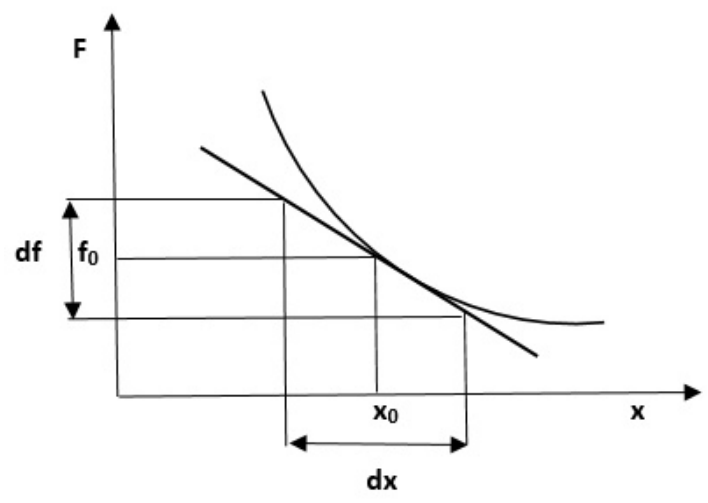

Source: Autor's own drawing

Figure 3: Linear approximation in parameter value area

Also, so called relative sensitivity can be used:

$$
S_{r_{x}}^{F}(p, x)=\frac{d F(p, x)}{d x} \cdot \frac{x_{0}}{F_{0}}
$$


where $x_{0}$ and $F_{0}$ represent nominal values. Function $F(p, x)$ can be determined after calculating algebraic complements in equation (2) as:

$$
F(p, x)=\frac{N(p, x)}{D(p, x)}
$$

where $N(p, x)$ and $D(p, x)$ are polynomials with variable $p$ and changing parameter $x$.

Actually, relative sensitivity (4) represents a sensitivity function because variables $p$ and $x$ figure within. After substituting nominal values $p=j \omega_{0}, x=x_{0}$ numeral data figuring sensitivities are obtained.

Calculating sensitivities cane be carried out by the following equation:

$S_{r_{x_{i}}}^{F}\left(p, x_{i}\right)=x_{i}\left(\frac{N^{\prime}}{N}-\frac{D^{\prime}}{D}\right)$

which enables to avoid more complexed deriving function ratio (Moos, Vytlačil 1991).

At analysing heat damping, amplitude of heat divergences distributed through constructions and time offsets (phase offsets) of heat excitements at passing through construction are of special importance. Heat inertia of individual building constructions can be determined by dimensionless quantity heat damping $v$ which is equal to a ratio of amplitude of exterior air temperature variation $A_{e}$ to amplitude of interior surface temperature $A_{\text {is }}$ (Figure 4) :

$$
v=\frac{A_{e}}{A_{i s}}
$$

Periodically changing temperature of exterior air causes periodical temperature change on interior construction surface (provided temperature of interior air is constant) as shown on Figure 3 (Sangi et al., 2016). During the process time offset of temperature amplitudes called phase offset $\Psi$ can be observed as shown on Figure 5.

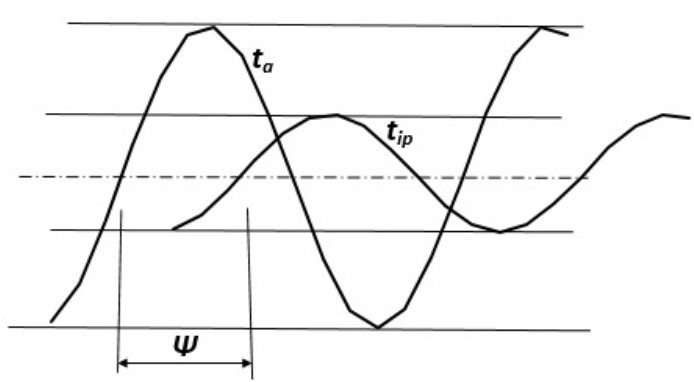

Source: Autor's own drawing

Figure 5: Temperature amplitudes time offset.

By use of Fourier transform - or Fast Fourier transform; FFT (Bracewell, 1999) - time progress of temperature change can be decomposed to a set of harmonic components characterized by appropriate phase amplitude (Svoboda, 2012). At calculating sensitivities of amplitudes and phases to changes of parameters, derivations of both module and phase functions derived from system function $F(j \omega, x)$ need not be calculated individually but in bulk thank to the fact that a real part of the sensitivity function (4) after substituting $p=j \omega$ directly represents sensitivity of temperature amplitude an imaginary part represents sensitivity of phase delay to change of parameter $x$. It can be determined as:

$$
\begin{aligned}
S_{r_{x_{i}}}^{F}(j \omega) & =R e \cdot S_{r_{x_{i}}}^{F}+j \cdot I m \cdot S_{r_{x_{i}}}^{F} \\
& =\frac{d\left|F\left(j \omega, x_{i}\right)\right|}{d x_{i}} \cdot \frac{x_{i}}{\left|F\left(j \omega, x_{i}\right)\right|}+j \cdot \frac{d\left\{\arg F\left(j \omega, x_{i}\right)\right\}}{d x_{i}}
\end{aligned}
$$

Graphs of the functions:

$R e \cdot S_{r_{x_{i}}}^{F}$ and $\operatorname{Im} \cdot S_{r_{x_{i}}}^{F}$

represent sensitivity characteristics.

A differential characterizing heat transfer:

$$
\Delta \mathrm{F}=\sum_{i=1}^{n} S_{x_{i}}^{F} \cdot \Delta x_{i}
$$
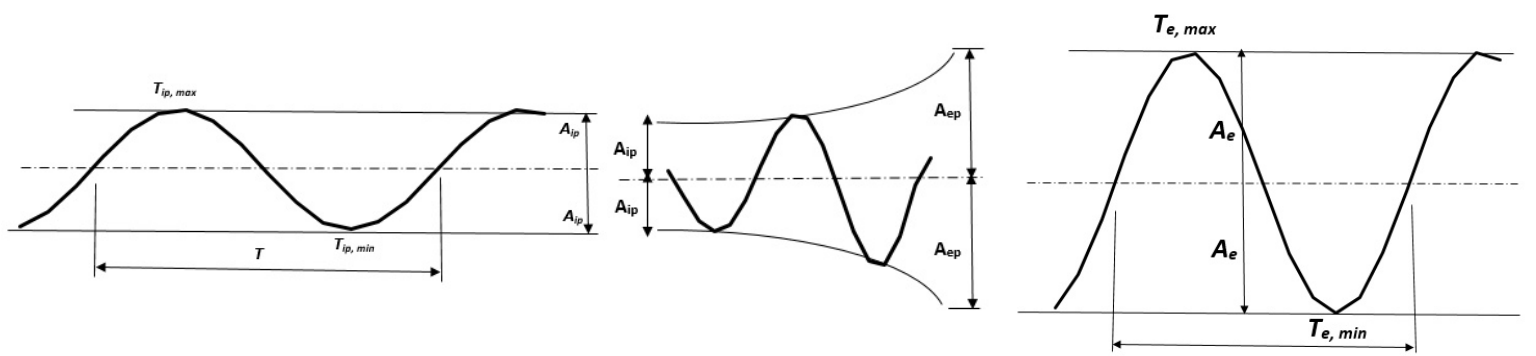

Source: Autor's own drawing

Figure 4: Heat damping characteristics. 
represents tolerance of system function $F\left(x_{i}\right)$, while relative tolerance is defined as:

$$
\frac{\Delta \mathrm{F}}{\mathrm{F}}=\sum_{i=1}^{n} S_{r_{x_{i}}}^{F} \cdot \frac{\Delta x_{i}}{x_{i}}
$$

Resulting signs of partial tolerances can be different and effects of changes may be compensated to a certain extent (Dong et al., 2015). The worst scenario occurs when all partial tolerances of the same signs are added. It can be defined by the equation:

$$
\frac{\Delta \mathrm{F}}{\mathrm{F}}=\sum_{i=1}^{n} \sqrt{\left(S_{r_{x_{i}}}^{F} \cdot \frac{\Delta x_{i}}{x_{i}}\right)^{2}}
$$

Analysis of the worst case of tolerances effects is of great significance because it enables to avoid undesirable impacts of production spread of building constructions parameters (Evola and Marletta, 2013).

While formulas of system function tolerances $(12,13)$ describe current effect of tolerances of all considered parameter so called sensitivity matrix enable transparent arrangement of partial tolerances and represents an useful tool for considering dominant construction parameters from the viewpoint of both temperature amplitudes and time (phase) offsets (Moos, Vytlačil 1991). A sensitivity matrix is defined as:

$\left[\begin{array}{c}I F ! \\ \varphi\end{array}\right]=\left[\begin{array}{c}S_{11}, S_{12}, \ldots, S_{14} \\ S_{21}, S_{22}, \ldots, S_{24}\end{array}\right] \cdot\left[\begin{array}{c}x_{1}^{*} \\ x_{2}^{*} \\ \cdot \\ x_{4}^{*}\end{array}\right]$

Values $S_{i}$ represent sensitivity amplitudes and phases of heat transfer while $x_{2 i}^{*}$ represent values of native tolerances.

\section{Results and discussion}

The theory was verified on an example of a poultry farm represented by a simplified system macromodel shown on Figure 1 transformed into heat circuit scheme shown on Figure 2 (Moziraji at al., 2014). Calculations were carried out for all elements in the macromodel for three categories of perimeter walls of different material composition (Table 2, 3) by means of ANATH application (Rochla, 1983). The following values were entered into the calculating process.

Result values are graphically shown on Figure 6 in the form of the histogram of temperature changes transfer for three construction types containing both amplitude (real part) and phase (imaginary part) properties.

Primarily, the interior heat capacity and window heat conductivity are significant for both types of sensitivities while perimeter wall heat capacity and conductivity affect the values to a lesser degree (Zajicek and Kic, 2014). The perimeter wall heat conductivity is a dominant one from the point of stationary heat transfer. Other elements are of no consequence. The graphs also show shifting sensitivities among the construction elements at change of a sole value (Malinovský, 1989).

Analyses of the graphs originated as outputs of ANATH show interesting effects of varying sensitivities at inputting different nominal values of the constructions parameters. The real and imaginary parts of transfer sensitivities of temperature changes from exterior environment are represented by separate curves - sensitivities are depicted on vertical axes while heat capacities, heat resistances, and regulation factors are depicted on horizontal axes as shown on Figures 7a-h (Moos, Vytlačil 1991).

\begin{tabular}{|c|l|l|c|}
\hline No & Category & Material & Thickness [m] \\
\hline 1 & light & chipboard, mineral felt, wood-fibre (Sololit) & 0.11 \\
\hline 2 & medium & brickwork & 0.6 \\
\hline 3 & heavy & stone wall & 1.2 \\
\hline
\end{tabular}

Source: Malinovský, V. (1989)

\begin{tabular}{|c|c|c|c|c|c|c|c|c|}
\hline No & $\begin{array}{c}C_{K} \\
{\left[\mathrm{~W} \times \mathrm{h} \times \mathrm{K}^{-1}\right]} \\
\end{array}$ & $\begin{array}{c}K \\
{\left[\mathrm{~K}^{2} \times \mathrm{W}^{-1}\right]} \\
\end{array}$ & $\begin{array}{c}\alpha_{i} \\
{\left[\mathrm{~K} \times \mathrm{W}^{-1}\right]} \\
\end{array}$ & 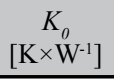 & $\begin{array}{c}C_{i} \\
{\left[\mathrm{~W} \times \mathrm{h} \times \mathrm{K}^{-1}\right]}\end{array}$ & $\begin{array}{c}\alpha_{t} \\
{\left[\mathrm{~K} \times \mathrm{W}^{-1}\right]}\end{array}$ & $\begin{array}{c}C_{t} \\
{\left[\mathrm{~W} \times \mathrm{h} \times \mathrm{K}^{-1}\right]}\end{array}$ & $\begin{array}{c}Q \\
{\left[{\left.\mathrm{~W} \times \mathrm{K}^{-1}\right]}^{-1}\right.}\end{array}$ \\
\hline 1 & 202 & \multirow{3}{*}{11} & \multirow{3}{*}{84.5} & \multirow{3}{*}{4.2} & \multirow{3}{*}{2000} & \multirow{3}{*}{20} & \multirow{3}{*}{100} & \multirow{3}{*}{100} \\
\hline 2 & 2210 & & & & & & & \\
\hline 3 & 6350 & & & & & & & \\
\hline
\end{tabular}

Table 2: Types of perimeter walls.

Note: $K$ - heating transfer coefficient (wall); $K_{0}$ - heating transfer coefficient (glass-walled part); $C_{K}$ - heat capacity of perimeter wall; $C_{i}$ - heat capacity of interior; $C_{t}$ - heat capacity of heating system; $Q$ - regulation factor; $\alpha_{i}$ - heat transfer from perimeter wall to interior; $\alpha \mathrm{t}$ - heat transfer from heating system to interior. Source: Malinovský, V. (1989) 
Rea1 Part

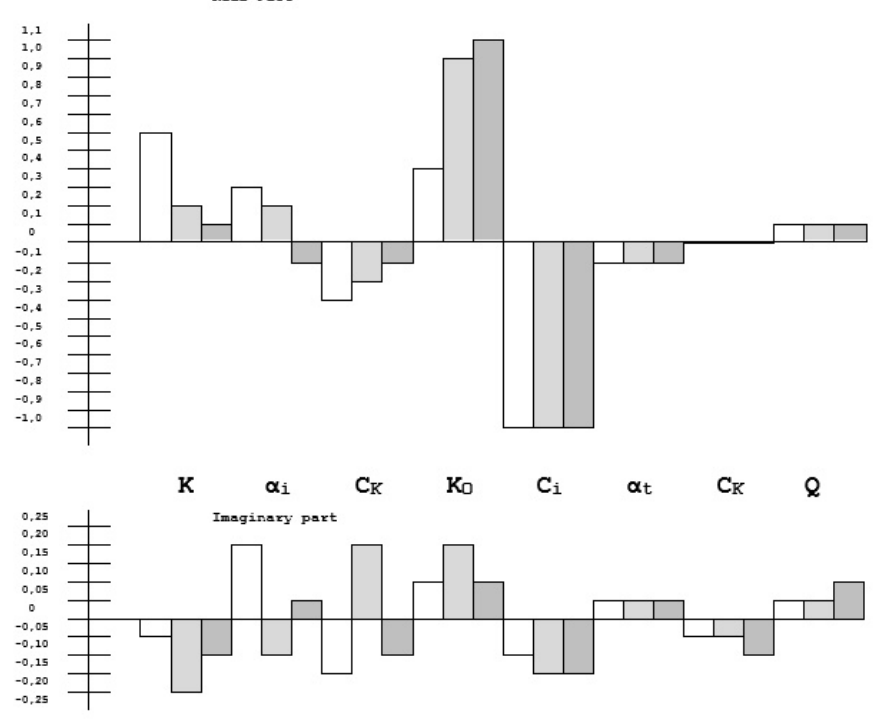

Note: Constructions: light (white), medium (light grey), and heavy (dark grey); $K$ - heating transfer coefficient (wall); $K_{0}$ - heating transfer coefficient (glasswalled part); $C_{K}$ - heat capacity of perimeter wall; $C_{i}$ - heat capacity of interior; $C_{t}$ - heat capacity of heating system; $Q$ - regulation factor; $\alpha_{i}$ - heat transfer from perimeter wall to interior; $\alpha \mathrm{t}$ - heat transfer from heating system to interior. Source: Autor's own research and processing

Figure 6: Histogram of transfer sensitivities.

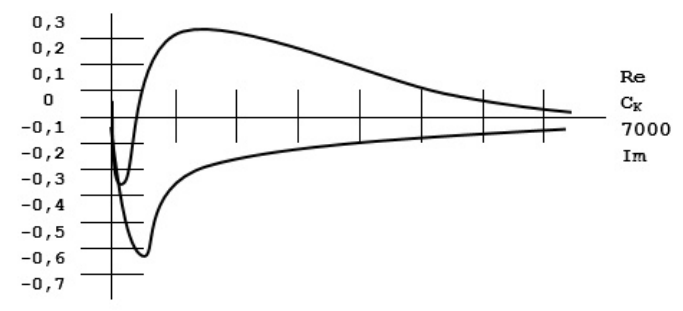

Figure 7a: $C_{K}$ - heat capacity of perimeter wall.

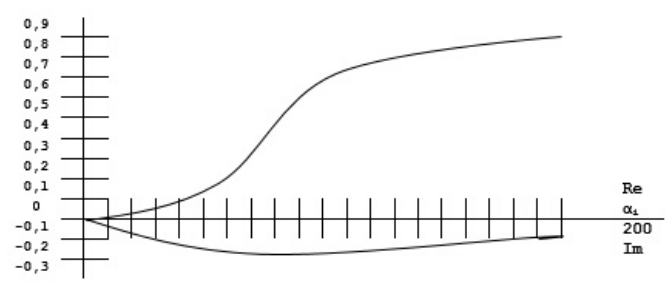

Figure 7c: $\alpha_{i}$ - heat transfer from perimeter wall to interior

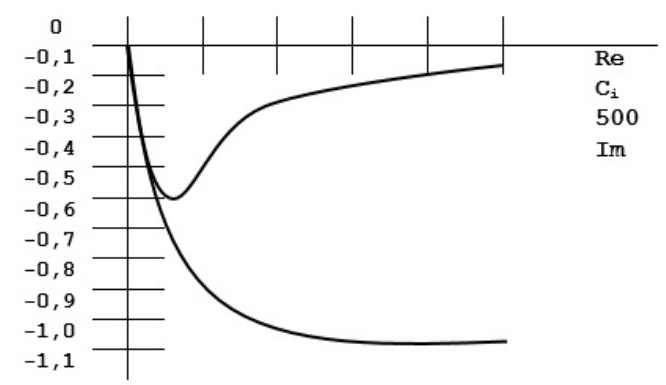

Figure 7e: $C_{i}$ - heat capacity of interior

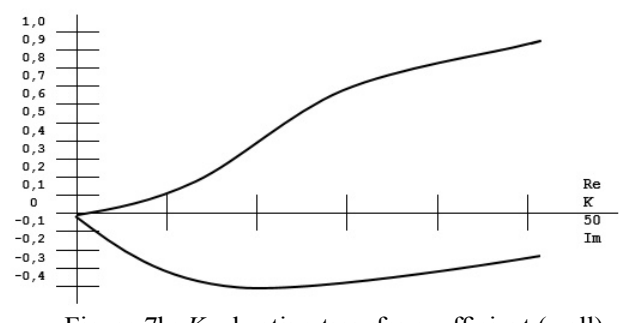

Figure $7 \mathrm{~b}: K$ - heating transfer coefficient (wall)

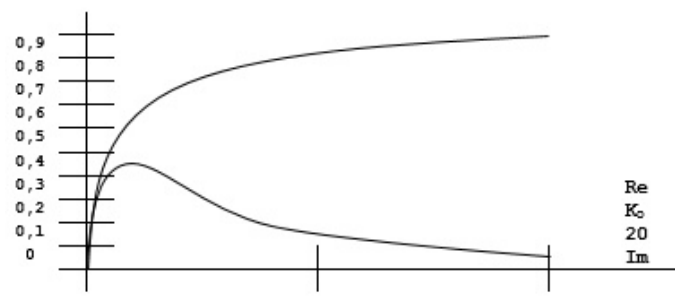

Figure 7d: $K_{0}$ - heating transfer coefficient (glass-walled part).

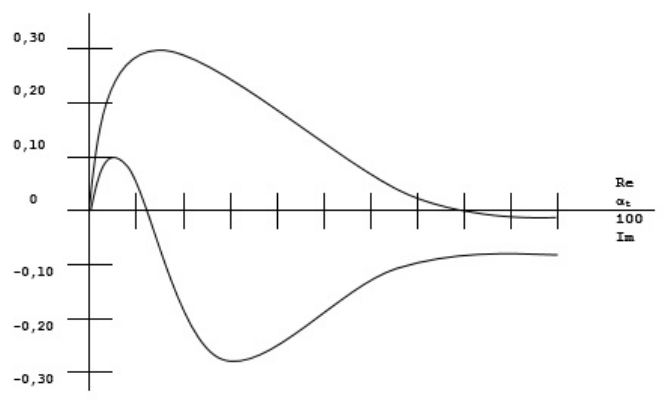

Figure 7f: $\alpha_{t}-$ heat transfer from heating system to interior

Source: authors' own processing in ANATH

Figure 7a-h: Transfer sensitivities of temperature changes (to be continued). 


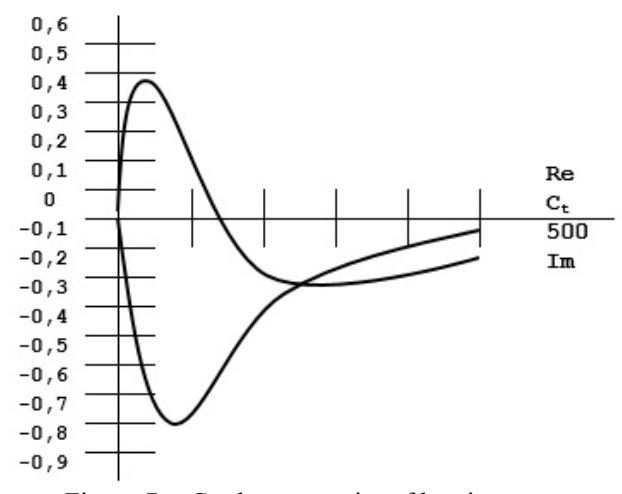

Figure $7 \mathrm{~g}: C_{t}-$ heat capacity of heating system

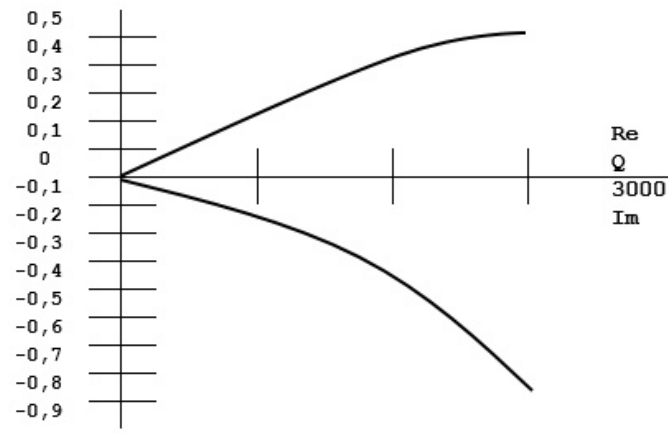

Figure 7h: $Q$ - regulation factor

Source: authors' own processing in ANATH

Figure 7a-h: Transfer sensitivities of temperature changes (continuation).

\section{Discussion}

According to (12), these values were used for determining a new course of the temperature $T$ corresponding with a changed conductivity value $K$. The original and new course are shown on Figure 8a. Further, comparison of the course with the values determined by the analysis were carried out by ANATH application for both the original and changed wall conductivity value. Results are shown on Figure $8 \mathrm{~b}$ and a newly obtained course of both the methods does not differs more than $3 \%$ which represents a very good concordance of results obtained by the sensitivity method and analysis (Mehta and Woods, 1981). Together with a larger change of the element value, inaccuracy increases because the F function course is nonlinear (Moos, Vytlačil 1991).

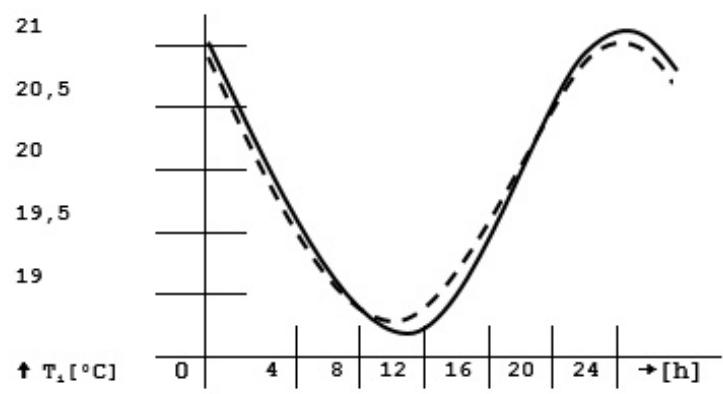

Source: authors' own processing in ANATH

Figure 8a: Temperature courses depending on heating transfer coefficient change.

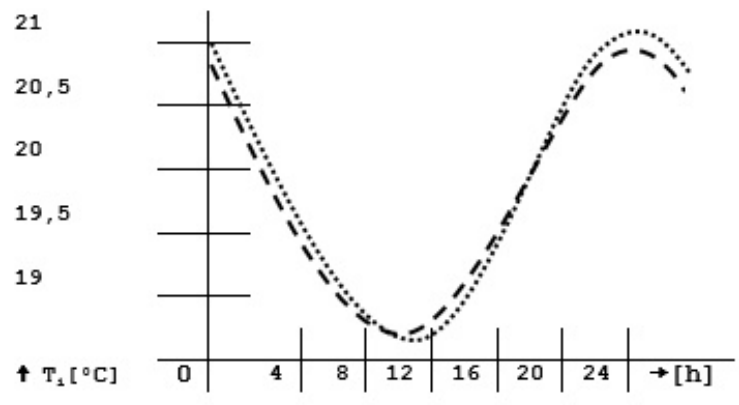

Source: authors' own processing in ANATH

Figure 8b: Temperature courses obtained by measurement and calculation.

At the particular nod of the construction system macromodel, sensitivity analysis enables to obtain a change of temperature course (Hoffman and Feldman, 1981). The analysis need not be repeated, results can be determined from sensitivity values of amplitude range $\mathrm{ReSr}$ (Real sensitivity) and phase sensitivity delay $\mathrm{ImSr}$ (Imaginary sensitivity) (Lloyd et al., 1978). Verification of the method was carried out by calculating the interior temperature change at increased heat conductivity value of the perimeter construction (wall) by $10 \%$. The ANATH application calculated both the values $\mathrm{ReSr}=0.634$ and $\mathrm{ImSr}=-0.062$ for a particular nominal value and generated graphs of sensitivities depending on a nominal value of a selected element. 


\section{Conclusion}

The used sensitivity methods is effective for determining resulting course of temperature at frequent changing value of only or more construction elements. In some cases the sensitivity method can be applied even instead of synthesis including searching for element values for requested amplitude and time offset, however, it is important to remember the theory of linear sensitivities outputs quality results for lesser changes of perimeter elements values only. In case of greater changes, it should be used progressive sensitivities calculating according to a way of changing nominal values or, alternatively, the method of non-linear sensitivities considered as very significant one for building constructions.

Mutual sensitivity rate among individual elements

\section{Corresponding authors}

Ing. Vit Malinovský, Ph.D.

Department of System Engineering, Faculty of Economics and Management

Czech University of Life Sciences Prague, Kamýcká 129, 16500 Praha-Suchdol, Czech Republic

Phone:+420606482119,E-mail:vit.malinovsky@volny.cz,malinovskyv@pef.czu.cz

\section{References}

[1] Bracewell, R. (1999) “The Fourier Transform \& Its Applications", McGraw-Hill, New York, USA. ISBN 978-00-730-3938-1, DOI 10.4236/am.2018.94026.

[2] Chloupek, J. (2012) “Posuzování tepelné bilance a větrání stájových objektů pro hospodářská zvírata", multimedial textbook učební text”, University of Veterinary and Pharmaceutical Sciences Brno, Brno (In Czech).

[3] Cooke, J. R. and DeBaerdemaeker, J. G. (1975) "Transient Thermal Behavior Of Agricultural Buildings, Including Subsurface Heating”, Paper - American Society of Agricultural Engineers.

[4] Dong, Z., Zhu, P., Bobker, M. and Ascazubi, M. (2015) "Simplified characterization of building thermal response rates", Energy Procedia, Vol. 78, pp. 788-793. ISSN 1876-6102. DOI 10.1016/j.egypro.2015.11.098.

[5] Evola, G. and Marletta, L. (2013) "A dynamic parameter to describe the thermal response of buildings to radiant heat gains", Energy and Buildings, Vol. 65, pp. 448-457. ISSN 0378-7788. DOI 10.1016/j.enbuild.2013.06.026.

[6] Hoffman, M. E. and Feldman, M. (1981) "Calculation of the thermal response of buildings by the total thermal time constant method", Building and Environment, Vol. 16, No. 2, pp. 71-85. ISSN 0360-1323. DOI 10.1016/0360-1323(81)90023-8.

[7] Hulzebosch, J. (2005) "Climate in Poultry Houses”, [Online]. Available: http://www.poultryhub.org/ production/husbandry-management/housing-environment/climate-in-poultry-houses/ [Accessed: 12 Dec. 2018]. CJ Hawkins Homestead, University of New England, Armidale, Australia.

[8] Jokl. M. (1989) “TZB - technická zařizení budov II: Interní mikroklima, ventilační a klimatizačni technika pro stavební inženýry”, Czech Technical University in Prague (In Czech).

[9] Lloyd, J. R. and Davisson, M. C. (1978) "Simulation of the Thermal Response of Buildings to Changes in the Environment", Modeling and Simulation, Proceedings of the Annual Pittsburgh Conference, Vol. 9, (pts 1-4), pp. 295-300. 
[10] Malinovský, V. (1989) "Systémový makromodel pro analýzu spotřeby energie s ohledem na její minimalizaci", diploma thesis, Czech Technical University in Prague (In Czech).

[11] Malinovský, V. (2018) "System Macromodel of Agricultural Building with Aim to Energy Consumption Minimization", AGRIS on-line Papers in Economics and Informatics, Vol. 10, No. 1, pp. 25-35. ISSN 1804-1930. DOI 10.7160/aol.2018.100103.

[12] Mehta, D. P. and Woods, J. E. (1981) "Accuracy of an Analytical Model to Predict Dynamic Thermal Responses of Building Systems", Proceedings of the National Conference on Power Transmission, pp. 457-469.

[13] Moos, P. (1989) "Počítačový makromodel tepelného mikroklimatu budov", Pozemní stavby, Vol. 2, pp. 92-96 (In Czech).

[14] Moos, P. and Vytlačil, D. (1991) "Citlivosti prenosu tepla na parametry stavebních konstrukcí", Energetika, Vol. 2, pp.45-49 (In Czech).

[15] Moziraji, Z. P., Azimi, A. and Hannani, S. K. (2014) "Analysis and modeling of building thermal response to investigate the effect of boundary conditions", Scientia Iranica, Vol. 20, No. 4, pp. 1269-1277. E-ISSN 2345-3605, ISSN 1026-3098.

[16] Pöttgen, P., Ederer, T., Altherr, L., Lorenz, U. and Pelz, P. F. (2015) "Examination and Optimization of a Heating Circuit for Energy-Efficient Buildings", Energy Technology, Vol. 4, No. 1, pp. 136-144, E-ISSN 2194-4296, ISSN 2194-4288. DOI 10.1002/ente.201500252.

[17] Rochla. M. (1983) “Stavebni tabulky”, textbook, SNTL-Alfa, Prague, (In Czech).

[18] Sangi, R., Baranski, M., Oltmanns, J., Streblow, R. and Müller, D. (2016) "Modeling and simulation of the heating circuit of a multi-functional building", Energy and Buildings, Vol. 110, pp. 13-22, ISSN 0378-7788. DOI 10.1016/j.enbuild.2015.10.027.

[19] Sonderegger, R. C. (1977) "Harmonic analysis of building thermal response applied to the optimal location of insulation within the walls", Energy and Buildings, Vol. 1, No. 2, pp. 131-140. ISSN 0378-7788. DOI 10.1016/0378-7788(77)90025-1.

[20] Svoboda, J. (2012) "Mikroklima budov ve vztahu k energetické náročnosti", Brno University of Technology, Fakulty of Architecture, Brno. ISBN 978-80-214-4463-8 (In Czech).

[21] Veverka, J., Chybík, J. and Sedlák, R. (1992) "Energetické hodnocení budov a tepelná pohoda vnitřního prostředí, Brno University of Technology, (In Czech).

[22] Výmola, J. (1995) "Drůbež na farmách a v drobném chovu", Nakladatelství Apros, Prague, 192 p. ISBN 80-901100-4-5 (In Czech).

[23] Wachowicz, E., Raczek, A. and Woroncow, L. (2016) "The use of optimization of energy-saving microclimate control in selected agricultural objects", Journal of Research and Applications in Agricultural Engineering, Vol. 61, Nr. 1, pp. 119-123, Przemysłowy Instytut Maszyn Rolniczych. ISSN 1642-686X. (In Polish).

[24] Zajicek, M. and Kic, P. (2014) "Heating of large agricultural and industrial buildings", Agronomy Research, Vol. 12, No. 1, pp. 237-244. ISSN 1406-894X. 